\title{
Hydration of Tetracalcium Aluminoferrite in an Acetic Acid Solution
}

\author{
Minoru FUKUHARA, Masao INOUE, Kazuhiro YAMAGUCHI and Akira DOI \\ $\left(\begin{array}{l}\text { Department of Applied Chemistry, Faculty of Engineering, Okayama University of Science, } \\ 1-1 \text {, Ridai-cho, Okayama-shi } 700\end{array}\right)$ \\ テトラカルシウムアルミノフェライトの酢酸水溶液中での水和反応
}

\author{
福原実・井上正生・山口一裕・土井章 \\ (岡山理科大学工学部応用化学科, 700 岡山市理大町 1-1)
}

Tetracalcium aluminoferrite was hydrated at $25^{\circ} \mathrm{C}$ with acetic acid solutions. The hydration rate of tetracalcium aluminoferrite was retarded remarkably when $1.00 \mathrm{~mol} / \mathrm{l}$ acetic acid solution was used. When distilled water, 0.10 and 0.25 mol/l acetic acid solutions were used, tetracalcium aluminate tridecahydrate was formed. However, a hydrate characterized by two X-ray diffraction peaks with spacings of 10.9 and $5.4 \AA$ appeared when 0.50 to $1.00 \mathrm{~mol} / \mathrm{l}$ acetic acid solutions were used. This hydrate was stable up to $150^{\circ} \mathrm{C}$ in air, and was a complex of organic-tetracalcium aluminate hydrate. Acetic acid molecules were probably sorbed in the interlayer region of tetracalcium aluminate hydrate.

[Received June 7, 1989; Accepted September 18, 1989]

Key-words : Cement, Tetracalcium aluminoferrite, Hydration, Acetic acid

\section{Introduction}

There are many papers concerning the sorption of organic molecules on inorganic layer crystal. Clay minerals are well known as host inorganic materials. ${ }^{1)}$ Tetracalcium aluminate hydrates (hereinafter abbreviated to $\mathrm{C}_{4} \mathrm{AH}_{x}{ }^{*}$ ) formed in the hydration process of portland cement also have a layer structure, and they are able to sorb organic molecules in the crystal. ${ }^{2)}$ These $\mathrm{C}_{4} \mathrm{AH}_{x}$ are hydration products of tricalcium aluminate $\left(\mathrm{C}_{3} \mathrm{~A}\right)$ and tetracalcium aluminoferrite $\left(\mathrm{C}_{4} \mathrm{AF}\right)$. Giving a review of researches on the formation of organic-inorganic complexes up to 1967, Dosh' confirmed the formation of organic complexes of $\mathrm{C}_{4} \mathrm{AH}_{x}$, and then concluded that the fatty acids could form the complexes with $\mathrm{C}_{4} \mathrm{AH}_{11}$. On the other hand, extensive research has been performed to clarify the effect of organic substances on the hydration process of portland cement. ${ }^{4)-6}$ ) Young $^{\text {() }}$ and Thomas et al. ${ }^{8)}$ proposed some retardation mechanisms by which organic substances influence the hydration process of portland cement. However, most research was carried out mainly with tricalcium silicate and tricalcium

* abbreviated nomenclatures are used in the present paper ; $\mathrm{C}=\mathrm{CaO}, \mathrm{A}=\mathrm{Al}_{2} \mathrm{O}_{3}, \quad \mathrm{~F}=\mathrm{Fe}_{2} \mathrm{O}_{3}$ and $\mathrm{H}=\mathrm{H}_{2} \mathrm{O}$. aluminate. ${ }^{\text {2),9) }} \mathrm{C}_{4} \mathrm{AF}$ is one of the four major clinker minerals, but hydration products of $\mathrm{C}_{4} \mathrm{AF}$ formed in the organic solutions have not been investigated in detail so far. Hydration products of $\mathrm{C}_{4} \mathrm{AF}$ are considered to have the same structure as those of $\mathrm{C}_{3} \mathrm{~A}$, but the substituted amount of iron to aluminium in the hydrates is not clear. ${ }^{10-12}$ )

In this paper, we investigated the hydration products of $\mathrm{C}_{4} \mathrm{AF}$ formed in acetic acid solutions, i. e., the simplest fatty acid, and hope to report some new findings concerning their properties.

\section{Experimental}

$\mathrm{C}_{4} \mathrm{AF}$ was synthesized in an electric furnace in an atmosphere of air for 4 hours at $1380^{\circ} \mathrm{C}$ from chemical grade $\mathrm{CaCO}_{3}, \mathrm{Al}_{2} \mathrm{O}_{3}$, and $\mathrm{Fe}_{2} \mathrm{O}_{3}$. Grinding and burning were repeated until unreacted reagents were no longer detected by X-ray diffraction (XRD). Synthesized $\mathrm{C}_{4} \mathrm{AF}$ was ground to a powder with $53 \mu \mathrm{m}$ or less in diameter. 1.00, $0.75,0.50,0.25$ and $0.10 \mathrm{~mol} / 1$ acetic acid solutions were used for the hydration. The weight ratio of $\mathrm{C}_{4} \mathrm{AF}$ to the solution was 1 to 1 . Pastes were cured at $25^{\circ} \mathrm{C}$ for 1 to 10 days. The hydrates were dried for 2 days in a vacuum vessel in which the water vapour pressure was $5 \times 10^{-4} \mathrm{mmHg}$ (D-dry). Phase identification of the hydrates was 
done by XRD and thermal analysis (DTA-TG). The amount of carbon in the hydrates was determined by total organic carbon analyzer (TOC). TG showed constant weight loss between $350^{\circ}$ and $600^{\circ} \mathrm{C}$, so TOC values refer to $1 \mathrm{~g}$ of the solids at $400^{\circ} \mathrm{C}$. An infrared analysis (IR) was applied to examine the state of acetic acid. Moreover, dried hydrates were heated at intervals of $50^{\circ} \mathrm{C}$ up to $350^{\circ} \mathrm{C}$ in a furnace for 2 hours in air. Phase identification and TOC measurement were also done after heat treatment. Rehydration of the heated hydrates was carried out at $25^{\circ} \mathrm{C}$ for 1 day. Rehydrated hydrates were dried as abovementioned. Distilled water was used for the rehydration, and the weight ratio of water to the heated hydrates was 1 to 1 .

\section{Results and discussion}

Figure 1 shows the XRD patterns of the hydrates of $\mathrm{C}_{4} \mathrm{AF}$ cured for 1 to 10 days with using various concentrations of acetic acid solution. According to these results, $\mathrm{C}_{4} \mathrm{AH}_{13}$ is formed when 0.10 and $0.25 \mathrm{~mol} / \mathrm{l}$ acetic acid solutions are added. However, the XRD intensity of this phase becomes weaker with the increase of the concentration of acetic acid. In contrast, new peaks, $d$ values of 10.9 and $5.4 \AA$, appear. The intensities of these peaks increase with the increase of the concentration of acetic acid. The value of $10.9 \AA$ is approximately double of the characteristic peak of tetracalcium aluminate hydrates of $5.4 \AA .{ }^{13)}$ A detailed account will be given later about this hydrate.

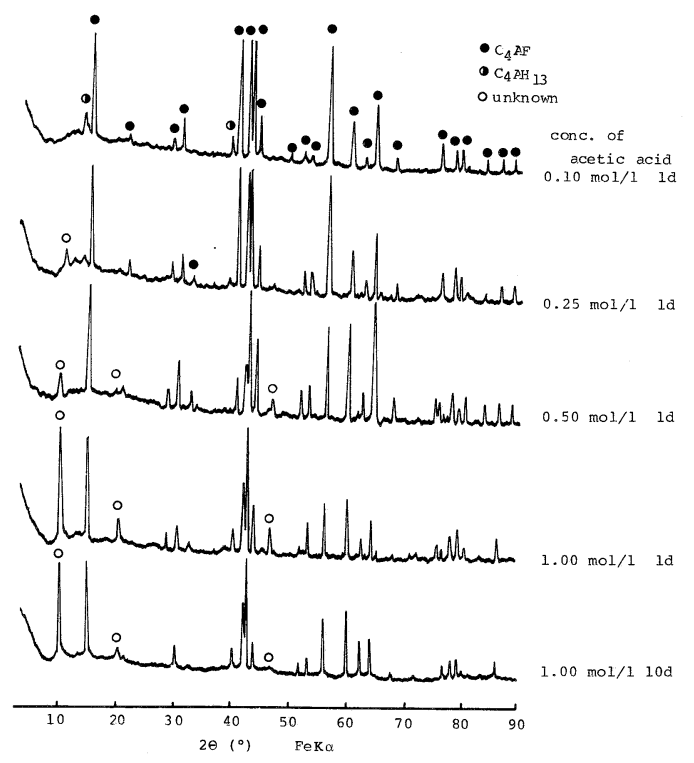

Fig. 1. XRD results of the hydrates in $\mathrm{C}_{4} \mathrm{AF}$-acetic acid soln. system. Hydration time was 1 day to 10 days.
It was also found that acetic acid could retard the rate of the hydration of $\mathrm{C}_{4} \mathrm{AF}$ from the results of XRD examination in which XRD patterns do not show any particular changes from 1 to 10 days when $1.00 \mathrm{~mol} / \mathrm{l}$ acetic acid solution is added. The hydrate which has XRD peaks of 10.9 and $5.4 \AA$ is seemingly very similar to $\mathrm{C}_{4} \mathrm{AH}_{19}$ with 0001 reflection at $10.6 \AA$ and 0002 reflection at 5. $32 \AA$ of $\mathrm{C}_{4} \mathrm{AH}_{19 .}{ }^{14)} \mathrm{C}_{4} \mathrm{AH}_{19}$ releases water molecules with an increase of temperature as $\mathrm{C}_{4} \mathrm{AH}_{19} \rightarrow$ $\mathrm{C}_{4} \mathrm{AH}_{13} \rightarrow \mathrm{C}_{4} \mathrm{AH}_{11} \rightarrow \mathrm{C}_{4} \mathrm{AH}_{7}$ without lossing its layer structure. Basal spacings of these hydrates are $10.6,8.2,7.9$ and $7.4 \AA$, respectively. ${ }^{3)}$ The

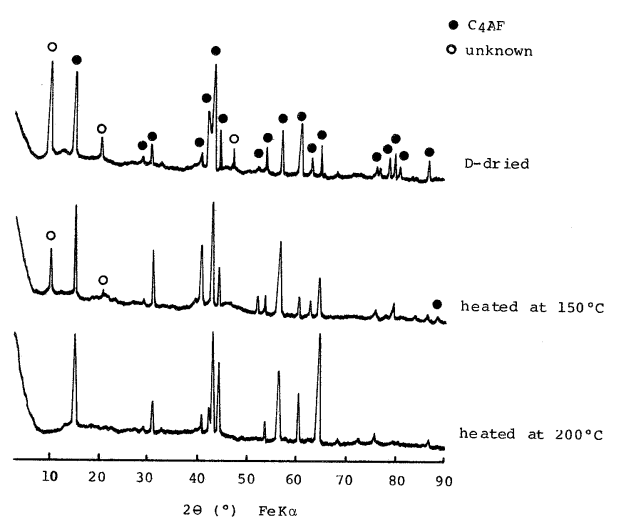

Fig. 2. Effect of the heating temperature on the hydrates in $\mathrm{C}_{4} \mathrm{AF}-1.00 \mathrm{~mol} / \mathrm{l}$ acetic acid soln. system.

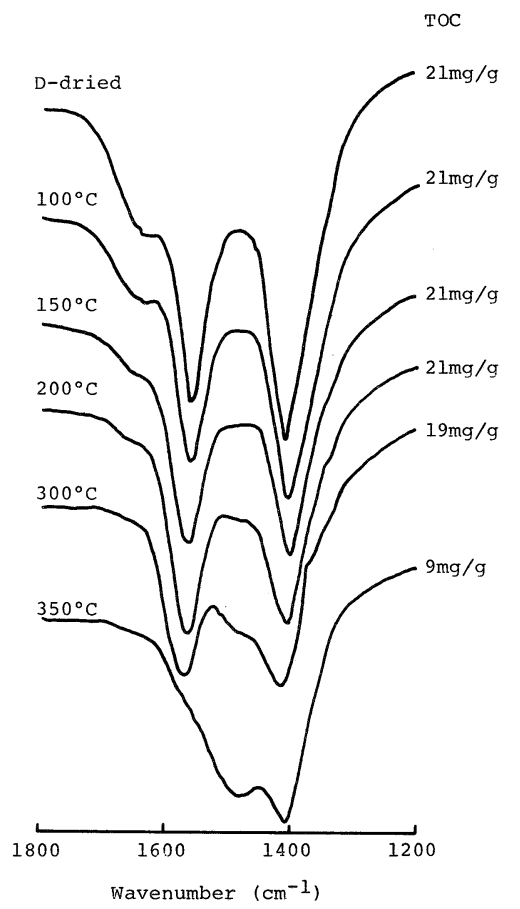

Fig. 3. IR and TOC results of heated hydrates in $\mathrm{C}_{4} \mathrm{AF}-1.00 \mathrm{~mol} / \mathrm{l}$ acetic acid soln. system. 
effects of the heating temperature on the hydrates are shown in Fig. 2. XRD results show that the two peaks of acetic acid hydrate of 10.9 and $5.4 \AA$ remained until $150^{\circ} \mathrm{C}$. without changing their values. Whereas stable phases of $\mathrm{C}_{4} \mathrm{AH}_{x}$ at $100^{\circ} \mathrm{C}$ and $150^{\circ} \mathrm{C}$ in air are $\mathrm{C}_{4} \mathrm{AH}_{13}$ and $\mathrm{C}_{4} \mathrm{AH}_{7}$, and the stable phase at $200^{\circ} \mathrm{C}$ is not clear. ${ }^{13)} \mathrm{XRD}$ intensities of the two peaks of acetic acid hydrate decrease with the increase of temperature and they disappeared at $200^{\circ} \mathrm{C}$. From these results, the hydrate which has two peaks of 10.9 and $5.4 \AA$ is not $\mathrm{C}_{4} \mathrm{AH}_{19}$ but an organic- $\mathrm{C}_{4} \mathrm{AH}_{x}$ complex. Figure 3 shows the IR and TOC results of heated hydrates. According to the result, two absorption bands of $1560^{-1} \mathrm{~cm}$ and $1410^{-1} \mathrm{~cm}$ are seen up to $300^{\circ} \mathrm{C}$. These are assigned to the symmetric vibration and asymmetric one of carbon-oxygen bond of carboxylate, respectively. ${ }^{15)}$ Organic component was burnt between $300^{\circ}$ and $350^{\circ} \mathrm{C}$ proved by DTA-TG. The amount of carbon in each of the heated hydrates is approximately the same up to $300^{\circ} \mathrm{C}$, and then considering the boiling point of acetic acid, $117.8^{\circ} \mathrm{C}$, the organic substance in the hydrates is not in the form of acid but of salt or chelate. ${ }^{16)}$

Figure 4 shows the XRD results of rehydrated products of pre-heated hydrates. It is found that two peaks, 10.9 and $5.4 \AA$, appear after rehydration of the hydrate heated at $200^{\circ} \mathrm{C}$. Considering the fact that there were no changes in the amount

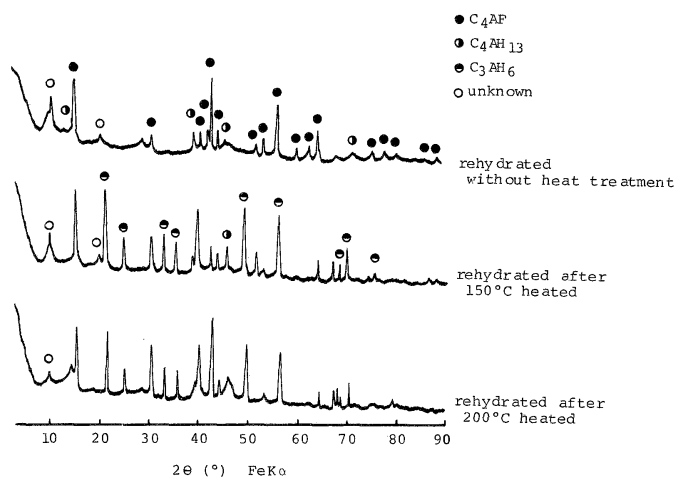

Fig. 4. XRD results of rehydrated products. Hydrates for the rehydration were heated at various temperatures. of carbon in the hydrates up to $300^{\circ} \mathrm{C}$, it is supposed that the organic molecules remain in the interlayer region of tetracalcium aluminate hydrate crystal at least up to $150^{\circ} \mathrm{C}$. Water lost tetracalcium aluminate hydrate heated at $200^{\circ} \mathrm{C}$ and organic molecules remained formed organictetracalcium aluminate hydrate again after rehydration. The character of the hydrates of $\mathrm{C}_{4} \mathrm{AF}$ formed in an acetic acid solution could be affected by heat treatment above $150^{\circ} \mathrm{C}$ since $\mathrm{C}_{3} \mathrm{AH}_{6}$ not found in acetic acid hydrates was formed when the heated hydrates were hydrated again.

It is concluded from these results that the hydration of tetracalcium aluminoferrite was remarkably retarded by $1.00 \mathrm{~mol} / \mathrm{l}$ of acetic acid solution, and acetic acid could form an organic complex of tetracalcium aluminate hydrate stable up to $150^{\circ} \mathrm{C}$ in air. Acetic acid molecules were probably sorbed in the interlayer region of the tetracalcium aluminate hydrate.

\section{References}

1) M.S. Whittingham and A. J. Jacobson, Ed., "Intercalation Chemistry", Academic Press, London and N. Y. (1982) pp. 55-99.

2) W. Dosch, Clays and Clay Minerals, 15, 273-92 (1967).

3) W. Dosch, Neues Jahrb. Mineral., 106, 200-39 (1967).

4) P.E. G. Banfill and D. C. Saunders, Cement and Concrete Res., 16, 399-410 (1986).

5) N. B. Singh, S. P. Singh and A. K. Singh, ibid., 16, 545-53 (1986).

6) S. Monosi, G. Moriconi, M. Pauri and M. Collepardi, 8 th Int'l Symposium on Chem. Cement, Brazil, Vol. 3 (1986) pp. 130-35.

7) J. F. Young, Cement and Concreat Res., 2, 415-33 (1972).

8) N.L. Thomas and D.D. Double, ibid., 11, 675-87 (1981).

9) H.F.W. Taylor and A.B. Burner, ibid., 17, 613-23 (1987).

10) M. Fukuhara, S. Goto, K. Asaga, M. Daimon, R. Kondo and Y. Ono, Yogyo-Kyokai-Shi, 88, 436-40 (1980).

11) F. Hannawayya, 8 th Int'l Symposium on Chem. Cement, Brazil, Vol. 3 (1986) pp. 217-24.

12) P.W. Brown, J. Am. Ceram. Soc., 70, 493-96 (1987).

13) F.G. Buttler, H.S.D. Glasser and H.F.W. Taylor, ibid., 42, 121-26 (1959).

14) H.F.W. Taylor, "The Chemistry of Cements", Vol.2, Academic Press, London and N.Y. (1964) p. 392.

15) K. Nakanishi, "IR Absorption Spectroscopy-Practice", Nanko-do, Tokyo (1960) p. 49.

16) Y. Yamamoto, Semento-Gijutsu-Nempo, 27, 148-52 (1973). 